\title{
ANALYSIS DICTION AND ANAPHORA LANGUAGE STYLE IN UNILEVER INDONESIA PRODUCT ADVERTISEMENT ON TELEVISION
}

\author{
Nia Tenia ${ }^{1}$, Rahmat Saripudin ${ }^{2}$ \\ ${ }^{1}$ IKIP Siliwangi \\ ${ }^{2}$ IKIP Siliwangi \\ ${ }^{1}$ niatenia93@gmail.com, ${ }^{2}$ rraka6@gmail.com
}

\begin{abstract}
The purpose of this study are (1) Describe the diction or choice of words in unilever product advertising. (2) Describe the anaphoric language style in unilever product advertising. (3) Describe the function of the sentence in unilever product advertising. Techniques used to collect data in this study is by library techniques, techniques refer, and method of record. Library technique is an attempt to find written or oral data sources that are documentation. Techniques refer to the technique of providing data with the use of language, while the technique of note is advanced techniques refer to the recording of both the written and oral advertisement of unilever products on television. The next step of the data is classified according to the issues discussed about word choice / diction, anaphoral language style, and sentence function in unilever product advertisement. Based on the analysis of diction, anaphora language style, and sentence function on unilever product advertisement on television. The findings derived in the form of dictionary peculiarities are indicated by the use of appropriate and varied expressions and symbols, the use of various terms from foreign languages, and various expressions deliberately exaggerated to reinforce meaning.
\end{abstract}

Keywords: Diction, Anaphoric, Sentence Function

\section{INTRODUCTION}

Advertising is one of the most widely used promotional form of companies in promoting their products (Munandar \& Priatna, 2007). Furthermore, according to (Tjiptono \& Fandy, 2005) says that Advertising is a form of indirect commmunication based on information about the advantagesof a product that is stacked in such a way that gives rise to a sense of fun that will change a person's mind to make a purchase. Advertising is no longer a new thing. It can be said that advertising has become a part of our daily lives whose presence we hardly ever realize that advertising is everywhere, even in the neighborhood. Tonefully persuaded a person's messages, both oral and written to buy the goods and services offered. Ads can provide information and instructions about goods and services that may be useful if prospective customers want to make a purchase of goods and services.

The ad form can be picture, photos, and even combined words from both. Given that ads in the form of picture or photographs without explanatory words will be difficult to understand by consumers who are targeted advertising, the researchers assume that in the ad, utterance or words is the most effective to describe and express the idea you want delivered so that there is a common interpretation between the ad maker and the advertising goals, so that the purpose of the holding can be achieved. 
According to (Badjuri \& Adi, 2010), Television is a media perspective as well as audio-visual audiences media,so the audience not only see the picture that aired television, but also hear or digest the narration of the image.Furthermore, according to (Ilham, 2010) television is a visual broadcast capture tool in the from of audio-visual and broadcasting of broadcasted broadcasting video. The word television comes from the Greek word from the word "Tele" which means seeing. So, if it is concluded literally means "seeing far away", because viewers are away from the television studios. Television is a modern medium in today's era. Television is one of the messenger media. One form of the message is delivered through the advertisement that aired as a pause in a television station show. Ads are served with the aim of influencing people to buy or consume products that have been offered. The most products offered such as food, household needs, and beauty products.

PT Unilever Indonesia has issued various products for daily needs of the people of Indonesia. Most of the advertisements aired on television are unilever products. A Company founded 1930 is headquartered in Rotterdam, The Netherlands offering several food, beverage, cleaning and personal consumer products. Some of Unilever's famous brands are: surf, Sunsilk, Dove, and Clear.

(Chaer \& Abdul, 1994) says that Language is unique, unique means to have specific characteristics that are not owned by other languages. Therefore there is no language higher than other languages. As an example of advertising offered by Unilever in a society with a form of Language that has a special characteristic that is to convince consumers to be interested, for example, the style of language that is delivered with the language is not standard or better known as the speech, like the word "buat" in the phrase "Wangi sexinya buat bidadari lupa diri "the sentence appears on the advertisement product Ax deodorant body spray.

The unique style of the language is able to anesthetize the consumer because of his curiosity and interest then arises the sense of wanting to have the product offered. The distinctiveness of the advertising language is short, dense, clear, and interesting. It therefore requires proper choice of words and the style of language (how to use language) to generate attractive ads and supported by the display model of advertising with a very varied message delivery. The variation of language can be selection by diction and the used of anaphora language style. According to (Ahmadi, 1990) diction is a selection of words to express ideas and feelings. Furthermore according (Mustakim, 1994) diction is the process or action of choosing words that can expresse ideas appropriately, while word choice is the result of the process or action.Based on the statement above can be concluded that diction is a process to selection word that express idea and feelings in a sentence.Morever that the researcher used of anaphora language style to analyze data.According to (Tarigan \& Guntur, 2009) anaphora is rhetorical form that is the use of words in speaking and writing to convince or influence the listening or reader. Furthermore, according to (Leech, N, \& Short, 1981) anaphora is use the language in a particular context, by a spesific person, for a spesific purposes.Based on the definition above can be concluded that anaphora language style is the used of word or language in speaking and writing to persuade and affect the listener and the reader.Based on the above description, the researcher tries to develop a research on the analysis of diction (word choice) and anaphora 
language style on Unilever Indonesia product advertisement on television. In this research try to be presented object of different study, that is advertisement.

\section{METHOD}

This research belongs to the type of descriptive qualitative research (Punch, 1998) says that qualitative research is empirical research where the data are not in the form of numbers. Accordingly, qualitative researchers deploy a wide range of interconnected methods, hoping always to get a better fix on the subject matter at hand (Denzin \& Lincoln, 1994). This research is more emphasis on the use of language style and word choice. Qualitative research is used if the problem is unclear, to know the meaning of the truth of the data, and examine the history of development.

In this research the technique that is used for this research is by non participant observation technique,because the data in this study is the diction and anaphora language style on the advertisement of Indonesian unilever product on television. Source of data in this research is Source of data taken from The advertisement that aired by television broadcasting station RCTI, Indosiar, SCTV, ANTV, MNC, Trans, and Trans 7. Selection of this station because the seven television station is a private television station that serve ads .

Data collection in this study using literature study techniques, refer to, then advanced techniques that is the technique of record.

1. Library study technique is a technique of data collection by searching for written and oral data sources that are documentation. The data is a book that is directly related to the object of research.

2. Technique identifying is a technique used in the provision of data by the researchers do the use of language saving.

3. Technique note is the advanced technique refer to the record of the results of the penalty both in writing and oral. This technique has an effective role in its application because recording or recording of written and oral writes can be helpful in providing data.

Data analysis is done by using apportion technique. This study uses the technique of apportion because the identifier is in the relevant language section itself (Sudaryanto, 1993). The method is done with the basic technique for the direct element. The basic technique for the element is the basic technique of the apportion which works by dividing the lingual unit of data into several parts.

\section{RESULTS AND DISCUSSION}

\section{Results}

Word or diction choices used in Unilever Indonesia product advertising include:

1. use of pronouns people, like aku,kamu dan dia/ me, you, and him

2. the use of foreign terms (English), such as spotless white uv, entertainer, sensation, fans, oil control etc. 
3. consonant beheading at the beginning of a word, as in the word "Gak" occurs 3. consonant beheading at the beginning of the word, as in the word No consonant dating occurs / $\mathrm{n} /$ and / g /, in the word"aja" occur consonant / s / date. This event can be explained as follows: Nggak : [n] [g] gak >> gak

Saja : [s] aja $>$ aja

4. the use of the short term, Seperti mutahir /like the last word: moderen atau terbaru/modern or latest, efektifleffective:membawa hasil/ bring results, evolusi/evolution: perubahan secara berangsur dan perlahan/change gradually and slowly, dan kalsium/and calcium: logam putih menyerupai kristal/white metal resembles crystals.

5. use of the word of speech, such as word Cuma/only, bikin/make, kog, trus, abis, pake, and dapet.

6. the use of common and special words, such as the word color includes red, brown, and white. The word dress includes clothing, said plate is one of the kitchen utensils and the word leaf includes leaf types.

7. use of the word konotaktif, such as New ax deodorant body spray. Her sexy scent makes her an angel forget herself./Baru axe deodorant body spray. Wangi seksinya bikin bidadari lupa diri.The word in bold is a connotative word.

The use of anaphororic language style in the advertisement of Unilever Indonesia product serves as the emphasis of a product, affirmation, notify the consumer, and the style of language is appended to increase the attractiveness and convince consumers of products or services offered. Examples of anaphoric language styles are repetitions of the first word in the next or next sentence.

Pond's oil control)

Hah..... Kulit berminyak/Huh ... oily skin.

Hey...... jangan panik/Hey ... ..don't panic.

Pond"s oil control baru dengan mineral clean. kulitku bebas kilap. Bebas kilap sepanjang hari/Pond "s new oil control with mineral clean. my skin is glossy. Free shine all day long.

Molto ultra

Wangi parfum ini, selalu membawa kenangan itu. Baru molto ultra sensation, sensasi kesegaran wangi parfum tahan lama. Baru molto ultra sensation./Smell this perfume, always bring the memories. New molto ultra sensation, durable perfume freshness sensation. New molto ultra sensation.

The word in bold in the sentence above is an anaphoric language style.

The function of the phrase in Unilever product advertisement is stated, among others:

1. Statement, such as example:

Clear

Entertainer itu tidak Cuma didengar, tapi juga dilihat. Rambut sering distling bisa bikin gatel, ketombean trus rontok. Gawat. Apa lagi tiap abis manggung pasti dicari fans. Tidak seperti 
shampoo lain Clear punya teknologi baru yang menguatkan kulit kepala dan mengatasi semua masalahnya. Sejak pakai clear ketombe dan rambut rontok, beres. Rock an roll trus. Aku pilih clear, kamu?

The entertainer is not only heard, but also seen. Hair often distling can make itchy, dandruff then fall off. Disastrous. Especially after each show is definitely looking for fans. Unlike other Clear shampoos have a new technology that strengthens the scalp and overcomes all the problems. Since the use of clear dandruff and hair loss, wrong. Rock an roll trus. I select clear, you?

The word bold in the ad above is a news sentence or statement.

\section{Questions, such as examples}

Citra

Siapa yang mau tebak warna dengan bu guru?/Who would guess color with bu guru?

Saya...../I.........

Ini warna apa?/What color is this?

Merah....yee/Red ... yee.

Coklat,Coklat/Brown, brown.

Ne cobain dech citra spotless white UV dengan kandungan ekstra beras jepang ./ Ne try use citra spotless white UV with extra content of japanese rice. Disguise black stains and protect the skin from the signs of aging due to sunlight.

Putih....itu cantik/White ... ...your beautiful.

Baru citra spotless white UV/New citra Spotless white UV.

Sentences of questions in this study are usually marked with the words how, why, what, and who.

3. Requests, sentences of orders or orders include both direct and indirect orders.

Citra

Siapa yang mau tebak warna dengan bu guru?/Who would guess color with bu guru?

Saya..../......

Ini warna apa?/What color is this?

Merah....yee /Red ... yee.

Coklat,Coklat /Brown, brown.

Ne cobain dech citra spotless white UV dengan kandungan ekstra beras jepang./Ne try use citra spotless white UV with extra content of japanese rice. Disguise black stains and protect the skin from the signs of aging due to sunlight.

Putih....itu cantik/White ... ..your beautiful.

Baru citra spotless white UV/New citra Spotless white UV. 
In the above ad there is the phrase " Ne cobain dech citra spotless white UV dengan kandungan ekstra beras jepang "The sentence includes a command / request (imperative) sentence. The sentence tells someone to try a new product spotless white UV image that contains extra Japanese rice.

4. Exclamation, this sentence is an expression of surprise and spontaneous speech. Like the following example:

Pond's oil control

Huh....Kulit berminyak/Huh ... oily skin

Hey.....jangan panik/Hey .....don't panic

Pond 'ee oil control baru dengan mineral clean kulitku bebas kilap. Bebas kilap sepanjang hari./Pond "s new oil control with mineral clean my skin is glossy. Free shine all day long.

The first and second sentences in the above advertisement include the exclamation call (ekslamatif). The exclamation phrase (ekslamatif) is a sentence expressed because of a sense of shock that causes spontaneous reaction of speakers. The phrase "hah ... oily skin", the sentence is an expression of shocked person because he saw his skin oily. In addition, the phrase "hey, do not panic" is a call for a spontaneous reaction to a person's complaints.

\section{Discussion}

The findings derived in the form of dictionary peculiarities are indicated by the use of appropriate and varied expressions and symbols, the use of various terms from foreign languages, and various expressions deliberately exaggerated to reinforce meaning. This study analyzed the diction and anaphora language style on Unilever Indonesia product advertisement on television. The findings are the diction or choice of words, general and specific words, conjunctive words, consonant beheading at the beginning of the word, person pronouns, and short terms.

\section{CONCLUSION}

Based on the above research results can be concluded as follow :

1. The choice of word or diction used in Unilever Indonesia product advertisment are: use of person pronoun as much as 3 data, usage of foreign term (english language) as much as 12 data, consonant beheading at the beginning of word as 1 data, use of short term counted 4 data, word usage as much as 4 data, general and special word usage of 3 data, and usage of word konotaktif 1 data.

2. The use of anaphora language style in the advertisement of Unilever Indonesia product serves as the emphasis of a product, affirmation, notify the consumer, and the style of language is appended to increase the attractiveness and convince consumers of products or services offered. The use of anaphora language style in unilever advertisement in this research is 13 data. 
3. Sentence function in Unilever product advertisement, among others, states statement as many as 4 data, question as much as 6 data, request as much as 4 data and appeal as much as 2 data. The function of this sentence is intended to increase the attractiveness and emphasis of the products offered. The sentences contain a specific purpose or purpose, such as the sentence intends to govern, provide information, declare news and product calls offered.

\section{ACKNOWLEDGMENTS}

Alhamdulillah all gratitude to Allah S.W.T who gave His blessing to researchers, so researchers can finish this article with good health condition. Researchers would like to say the biggest thank you for researchers' article supervisors who always gave researchers support when conducting this research. Also, researchers would like to say thank you to IKIP Siliwangi Bandung which gave us opportunity to publish this article. Also for blind reviewer who were reviews this article as well as to the editorial team so this article can be published perfectly.

\section{REFERENCES}

Ahmadi. (1990). Strategi Belajar Mengajar Keterampilan Berbahasa dan Apresiasi Sastra. Malang: Yayasan Asih Asah Asuh.

Badjuri, \& Adi. (2010). Jurnalistik Televisi. Yogyakarta: Graha Ilmu.

Chaer, \& Abdul. (1994). Linguistic umum. Jakarta: PT. Rineka cipta.

Denzin, N., \& Lincoln, Y. (1994). Handbook of Qualitative Research,Thousand Oaks. Calif: Sage.

Ilham. (2010). Kamus Istilah Televisi dan Film. Jakarta: Gramedia.

Leech, N, G., \& Short. (1981). Style in Fiction. London: A Longman Paperback.

Munandar, H., \& Priatna, D. (2007). Prinsip prinsip pokok periklanan dalam perspektif global. Jakarta: Kencana.

Mustakim. (1994). Membina kemampuan bahasa. Jakarta: Gramedia.

Punch, K. (1998). Introduction to Social Research: Quantitative and Qualitative Approches. London: Sage.

Sudaryanto. (1993). Metode dan Aneka Tekhnik Analisis Bahasa. Yogyakarta: Duta Wacana University Press.

Tarigan, \& Guntur, H. (2009). Pengkajian pragmatik. Bandung: Angkasa.

Tjiptono, \& Fandy. (2005). Pemasaran Jasa. Malang: Bayu Media Publishing. 